\title{
Differential regulation of two forms of gonadotropin-releasing hormone messenger ribonucleic acid by gonadotropins in human immortalized ovarian surface epithelium and ovarian cancer cells
}

\author{
Jung-Hye Choi, Kyung-Chul Choi, Nelly Auersperg and Peter C K Leung
}

Department of Obstetrics and Gynecology, British Columbia Children's and Women's Hospital, Child and Family Research Institute, University of British Columbia, 2H-30, 4490 Oak St, Vancouver, British Columbia, Canada, V6H 3 V5

(Requests for offprints should be addressed to P C K Leung; Email: peleung @interchange.ubc.ca)

\begin{abstract}
Although gonadotropin-releasing hormone $(\mathrm{GnRH})$ has been shown to play a role as an autocrine/ paracrine regulator of cell growth in ovarian surface epithelium and ovarian cancer, the factors which regulate the expression of $\mathrm{GnRH}$ and its receptor in these cells are not well characterized. In the present study, we employed real-time PCR to determine the potential regulatory effect of gonadotropins on the expression levels of GnRHI (the mammalian GnRH), GnRH II (a second form of $\mathrm{GnRH}$ ) and their common receptor (GnRHR) in immortalized ovarian surface epithelial (IOSE-80 and IOSE-80PC) cells and ovarian cancer cell lines (A2780, BG-1, CaOV-3, OVCAR-3 and SKOV-3). The cells were treated with increasing concentrations $(100$ and $1000 \mathrm{ng} / \mathrm{ml})$ of recombinant follicle-stimulating hormone (FSH) or luteinizing hormone (LH) for $24 \mathrm{~h}$. Treatment with FSH or LH reduced GnRH II mRNA levels in both IOSE cell lines and in three out of five ovarian cancer cell lines (A2780, BG-1 and OVCAR-3). A significant decrease in GnRHR mRNA levels was observed in IOSE and ovarian cancer cells, except CaOV-3 cells, following treatment with $\mathrm{FSH}$ or $\mathrm{LH}$. In contrast, treatment with either $\mathrm{FSH}$ or LH had no effect on GnRHI mRNA levels in these cells, suggesting that gonadotropins regulate the two forms of GnRH and its receptor differentially. In separate experiments, the effect of gonadotropins on the antiproliferative action of GnRHI and GnRHII agonists in IOSE-80, OVCAR-3 and SKOV-3 cells was investigated. The cells were pretreated with FSH or $\mathrm{LH}(100 \mathrm{ng} / \mathrm{ml})$ for $24 \mathrm{~h}$ after which they were treated with either $\mathrm{GnRHI}$ or $\mathrm{GnRH} I I(100 \mathrm{ng} / \mathrm{ml})$ for 2 days, and cell growth was assessed by the MTT [3-(4,5-dimethylthiazol-2-yl)-2,5-diphenyltetrazoliumbromide] assay. Pretreatment of the cells with FSH or LH significantly reversed the growth inhibitory effect of GnRHI and GnRH II agonists in these cell types. These results provide the first demonstration of a potential interaction between gonadotropins and the $\mathrm{GnRH}$ system in the growth regulation of normal ovarian surface epithelium and its neoplastic counterparts.
\end{abstract}

Endocrine-Related Cancer (2006) 13 641-651

\section{Introduction}

In addition to the classical form of mammalian gonadotropin-releasing hormone (GnRHI), a second form of GnRH (GnRHII) identical to chicken GnRHII has recently been found in the brain of primates including humans (Lescheid et al. 1997). Besides the hypothalamus and pituitary gland, GnRH I, GnRH II and their mutual receptor (GnRHR) have also been shown to be expressed in extrapituitary tissues including the ovary (Dong et al. 1993, Kang et al. 2001c). In the ovary, 
GnRH regulates the basal and gonadotropin-stimulated steroidogenesis in granulosa cells, and affects the expression of several genes related to folliculogenesis, ovulation and luteolysis (Peng et al. 1994, Kang et al. 2001b,c). Moreover, GnRH has been shown to be an autocrine regulator and has an anti-proliferative effect on gynecological cancers (Savino et al. 1992, Schally et al. 2001). In human ovarian surface epithelium and ovarian cancer, anti-proliferative and apoptosis inducing effects of GnRH have been demonstrated (Grundker \& Emons 2003, Kang et al. 2003). Recent studies indicate that GnRH may modulate the growth of ovarian cancer cells by decreasing epidermal growth factor receptor (EGFR) expression and telomerase activity, and increasing the p53/p21 and Fas ligand-Fas system (Emons et al. 1993, Nagata \& Golstein 1995, Ohta et al. 1998, Tang et al. 2002).

There is evidence that the expression of GnRH I, GnRH II and GnRHR is differentially regulated by its ligands, gonadal steroids (estrogen, progesterone and testosterone) and peptide hormones (activin, inhibin and gonadotropin) (Kang et al. 2001c, Khosravi \& Leung 2003, Cheng \& Leung 2005). In human ovarian surface epithelial (OSE) and granulosa luteal (GL) cells, treatment with GnRH I results in a biphasic response in its own ligand and receptor mRNA levels such that high concentrations decrease GnRHI and GnRHR mRNA levels whereas low concentrations increase the expression of both genes. In contrast, down-regulation of GnRH II and GnRHR mRNA levels was observed following treatment with GnRH II in GL cells (Kang et al. 2000, 2001c). Estradiol down-regulates GnRHI and GnRHR gene expression in GL cells and ovarian cancer (OVCAR-3) cells (Kang et al. 2001a, 2003). Gonadotropins have been shown to regulate the mRNA levels of GnRHI, GnRH II and GnRHR in the ovary (Peng et al. 1994, Olofsson et al. 1995, Kang et al. 2001c). In human GL cells, the expression of GnRH I and GnRH II is differentially regulated by follicle-stimulating hormone (FSH) and human chorionic gonadotropin (hCG) such that gonadotropins increase the mRNA levels of GnRHII but decrease those of GnRHI in a dose-dependent manner (Kang et al. 2001c). The expression of FSH receptor (FSHR) and luteinizing hormone receptor (LHR), and the growth-stimulating effect of their ligands in normal OSE and ovarian cancer cells has been demonstrated (Wimalasena et al. 1992, Kurbacher et al. 1995, Kobayashi et al. 1996, Mandai et al. 1997, Minegishi et al. 2000, Zheng et al. 2000, Ohtani et al. 2001, Parrott et al.
2001, Syed et al. 2001, Choi et al. 2002). However, the direct effect of gonadotropins on GnRH and GnRHR mRNA expression in human OSE and ovarian cancer cells remains to be elucidated. Considering that the two forms of GnRH may play an important role as autocrine/paracrine regulators in OSE and ovarian cancer, the present study was designed to investigate the role of gonadotropins in the regulation of GnRHI, GnRHII and GnRHR mRNA expression in human OSE and ovarian cancer cells. In addition, we also examined the ability of gonadotropins to modulate the growthinhibitory effects of the two GnRHs.

\section{Materials and methods}

\section{Cell culture and treatments}

Human luteinizing hormone (LH) and recombinant FSH were provided by Dr AF Parlow (National Hormone and Pituitary Program, Harbor-University of California Los Angeles Medical Center, Torrance, CA, USA). GnRH I analog (D-Trp6-GnRH) and GnRH II analog (D-Arg6-Azagly10-GnRH II) were purchased from Bachem (Belmont, CA, USA). Non-tumorigenic SV40 Tag-immortalized OSE-derived cells (IOSE-80) were cultured as previously described (Choi et al. 2001b) in medium 199:MCDB 105 (1:1; Sigma-Aldrich Corp., St Louis, MO, USA) containing $10 \%$ fetal bovine serum (FBS; Hyclone Laboratories Ltd, Logan, UT, USA), $100 \mathrm{U} / \mathrm{ml}$ penicillin $\mathrm{G}$ and $100 \mathrm{mg} / \mathrm{ml}$ streptomycin (Life Technologies, Inc., Rockville, MD, USA) in a humidified atmosphere of $5 \%$ $\mathrm{CO}_{2}-95 \%$ air at $37^{\circ} \mathrm{C}$. At confluency, the cells were passaged with $0.06 \%$ trypsin $(1: 250) / 0.01 \%$ EDTA in $\mathrm{Mg}^{2+} / \mathrm{Ca}^{2+}$-free Hank's Balanced Salt Solution (HBSS). The ovarian adenocarcinoma cell lines (A2780, BG-1, CaOV-3, OVCAR-3 and SKOV-3) were cultured in the above-mentioned culture conditions and used for the following experiments (Choi et al. 2001a). To investigate the regulation of GnRHI, GnRHII and GnRHR mRNA levels, cells were plated, cultured for $24 \mathrm{~h}$, and then treated for an additional $24 \mathrm{~h}$ with $\mathrm{FSH}$ or $\mathrm{LH}$ $(100$ or $1000 \mathrm{ng} / \mathrm{ml})$. Following treatment, the cells were lysed and immediately frozen at $-70^{\circ} \mathrm{C}$ until total RNA was extracted.

\section{Real-time RT-PCR}

Total RNA was prepared using TRIzol reagent (Invitrogen Canada, Burlington, ON, Canada), according to the manufacturer's instructions. Total 
Table 1 Primers used for the detection of GnRHI, GnRHII, GnRHR, FSHR, LHR and GAPDH by SYBR Green RT-PCR

\begin{tabular}{|c|c|c|c|c|c|}
\hline Gene & & SYBR Green primer sequence $\left(5^{\prime} \rightarrow 3^{\prime}\right)$ & $\% \mathbf{G C}^{\mathrm{a}}$ & $\mathrm{Tm}^{\mathrm{b}}$ & Amplicon size (bp) \\
\hline \multirow[t]{2}{*}{$\mathrm{GnRHI}$} & Forward & GCCTTAGAATGAAGCCAATTCAA & 39 & 62 & \\
\hline & Reverse & TCCACGCACGAAGTCAGTAGA & 52 & 62 & 62 \\
\hline \multirow[t]{2}{*}{ GnRHII } & Forward & TCTGTTCCССТCСААСТTTCTTC & 48 & 63 & \\
\hline & Reverse & AGGTCCATCCATCTTTCCTTCA & 46 & 62 & 64 \\
\hline \multirow[t]{2}{*}{ GnRHR } & Forward & ACCGCTCCСTGGCTATCAC & 63 & 63 & \\
\hline & Reverse & ACTGTTCCGACTTTGCTGTTGCT & 50 & 64 & 60 \\
\hline \multirow[t]{2}{*}{ FSHR } & Forward & TTTCAAGAACAAGGATCCATTCC & 39 & 61 & \\
\hline & Reverse & CCTGGCCCTCAGCTTCTTAA & 55 & 62 & 68 \\
\hline \multirow[t]{2}{*}{ LHR } & Forward & TTCAATGGGACGACACTGACTT & 46 & 62 & \\
\hline & Reverse & TGTGCATCTTCTCCAGATGTACGT & 46 & 63 & 64 \\
\hline \multirow[t]{2}{*}{ GAPDH } & Forward & ATGGAAATCCCATCACCATCTT & 41 & 62 & \\
\hline & Reverse & CGCCCCACTTGATTTTGG & 56 & 62 & 57 \\
\hline
\end{tabular}

a\% GC, guanine and cysteine percent of a primer sequence.

${ }^{\mathrm{b}} \mathrm{Tm}$, melting temperature.

RNA $(2.5 \mu \mathrm{g})$ was reverse transcribed into firststrand cDNA (Amersham Pharmacia Biotech, Oakville, ON, Canada) following the manufacturer's procedure. Briefly, the RNA solution was incubated at $65^{\circ} \mathrm{C}$ for $10 \mathrm{~min}$ and then chilled on ice. Five microliters of the bulk first-strand cDNA reaction mix, $1 \mu \mathrm{l} 200 \mathrm{mM}$ dithiothreitol, $1 \mu \mathrm{l} 0.2 \mu \mathrm{M}$ Not I$\mathrm{d}(\mathrm{T}) 18$ primer and the heat-denatured RNA were mixed, and incubated at $37^{\circ} \mathrm{C}$ for $1 \mathrm{~h}$.

The primers used for SYBR Green real-time RTPCR were designed using the Primer Express Software v 2.0 (Perkin-Elmer Applied Biosystems, Foster City, CA, USA) and are listed in Table 1. These primers are specific for FSHR, LHR, GAPDH, GnRHI, GnRHII and GnRHR, as demonstrated using the BLAST program (http:// www.ncbi.nlm.nih.gov), and were purchased from Invitrogen. To build a standard curve for each gene, cDNA fragments generated by RT-PCR were extracted from agarose gel bands and then used for 10-fold dilution. Real-time PCR was performed using the ABI prism 7000 Sequence Detection System (Perkin-Elmer Applied Biosystems) equipped with a 96-well optical reaction plate. The reactions were set up with $12.5 \mu \mathrm{l}$ SYBR Green PCR Master Mix (Perkin-Elmer Applied Biosystems), $7.5 \mu \mathrm{l}$ primer mixture $(300 \mathrm{nM})$ and $5 \mu \mathrm{l}$ cDNA template. Real-time PCR conditions were as follows: $52^{\circ} \mathrm{C}$ for $2 \mathrm{~min}$, followed by $95^{\circ} \mathrm{C}$ for $10 \mathrm{~min}$, and 40 cycles of $95^{\circ} \mathrm{C}$ for $15 \mathrm{~s}$ and $60^{\circ} \mathrm{C}$ for $1 \mathrm{~min}$. All real-time experiments were run in triplicate and a mean value was used for the determination of mRNA levels. Negative controls, containing water instead of sample cDNA, were used in each real-time plate. The standard curve quantitation method (ABI PRISM 7700 Sequence Detection System User Bulletin \#2) was used in this study, and the slope $(\mathrm{S})$ of the trend line represents the PCR efficiency. Deviation from $100 \%$ efficiency was determined by the equation: PCR efficiency $=10^{(1 /-\mathrm{s})}-1$. The amount of transcript in each sample was calculated by interpolation using the following formula: (threshold cycle-y intercept)/S. The copy number of FSHR, LHR, GnRHI, GnRH II and GnRHR mRNAs in each cell line was normalized to the amount of GAPDH mRNA.

\section{MTT assay}

Cell viability was estimated using the MTT [3-(4, 5-dimethylthiazol-2-yl)-2,5-diphenyltetrazoliumbromide] assay (Sigma-Aldrich Corp.). IOSE-80, OVCAR-3 and SKOV-3 cells were seeded in 96well plates and incubated for $24 \mathrm{~h}$. To examine the effect of FSH or LH on the growth-inhibitory effect of GnRH I and GnRH II agonists, IOSE-80, OVCAR-3 and SKOV-3 cells were pretreated with FSH or LH $(100 \mathrm{ng} / \mathrm{ml})$ for $24 \mathrm{~h}$ and then treated with GnRHI or GnRHII agonist for 2 days. On the day of collection, the cells were incubated at $37^{\circ} \mathrm{C}$ with $50 \mu \mathrm{l} \mathrm{MTT}$ solution $(2 \mathrm{mg} / \mathrm{ml}$ in phosphate-buffered saline (PBS)) for $4 \mathrm{~h}$. The supernatants were removed and the cells were solubilized in DMSO $(100 \mu \mathrm{l})$ for $30 \mathrm{~min}$. The optical density at $570 \mathrm{~nm}$ was determined using a microplate spectrophotometer (Fisher Scientific Ltd, Ottawa, ON, Canada). 


\section{Data analysis}

Data are shown as the mean \pm S.D. of three individual experiments performed in triplicate, and are presented as the mean. For the MTT assay, values are expressed as the percentage of growth compared with control and are presented as the mean \pm S.D. of three individual experiments performed in triplicate. Data were analyzed by one-way ANOVA followed by Dunnett's test. $P<0.05$ was considered statistically significant.

\section{Results}

\section{Validation of real-time RT-PCT for FSHR, LHR, GAPDH, GnRHI, GnRH II and GnRHR}

To examine whether the RT-PCR conditions produced primer-dimers and multiple amplicons, dissociation curve analysis and agarose gel electrophoresis were performed. Typical standard curves for the real-time amplification of FSHR, LHR, GnRHI, GnRHII, GnRHR and GAPDH were constructed (data not shown). Agarose gel electrophoresis of the amplicons yielded a single band (data not shown). The standard curve was loglinear for seven orders of magnitude (from $10^{2}$ to $10^{8}$ copies) and the coefficient of regression $\left(r^{2}\right)$ was $>0.98$. A dissociation curve analysis of FSHR, LHR, GnRHI, GnRHII and GnRHR amplicon resulted in a single peak (data not shown). The identity of the amplicons was confirmed to be FSHR, LHR, GnRHI, GnRHII, GnRHR and GAPDH by sequencing analysis.

\section{Expression of FSHR and LHR in IOSE and ovarian cancer cells}

In a recent study, we demonstrated the expression of FSHR protein in IOSE cells and ovarian cancer cells using Western blot. Low levels of FSHR protein were shown in IOSE-80PC (an IOSE-80 line derived post-crisis) and SKOV-3 (a potential invasive line) cells, whereas FSHR was highly expressed in OVCAR-3 cells (up to sevenfold higher) (Choi et al. 2004). In the present study, we evaluated the mRNA levels of FSHR and LHR among two IOSE cell lines (IOSE-80 and IOSE-80PC) and five ovarian cancer cell lines (A2780, BG-1, CaOV-3, OVCAR-3 and SKOV-3) using real-time RT-PCR (Fig. 1). We found that all seven cell lines expressed FSHR and LHR mRNA more than 0.0001 copy (ratio to GAPDH). The expression pattern of FSHR mRNA among IOSE-80, OVCAR-3 and SKOV-3 cells was similar to that of FSHR protein demonstrated in our previous study (Choi et al. 2004). No significant difference in either FSHR or LHR mRNA levels was observed between IOSE cells and ovarian cancer cells.

\section{Effect of FSH and LH on GnRHI, GnRH II and GnRHR}

To investigate whether GnRHI, GnRHII and GnRHR expression is regulated by FSH or LH in IOSE and ovarian cancer cell lines, the expression levels of GnRHI, GnRH II and GnRHR mRNA were examined following treatment of these cells with FSH or LH. The concentration of FSH and LH (100 and $1000 \mathrm{ng} / \mathrm{ml})$ was selected from previous results which showed that these doses caused functional changes in OSE or ovarian cancers (Choi et al. 2002, Pon et al. 2005). In all the cells examined including IOSE and ovarian cancer cells, no significant change in GnRH I mRNA levels was observed following treatment with gonadotropins (Fig. 2). However, treatment with gonadotropins induced a significant decrease $(\sim 60 \%)$ in GnRH II mRNA levels in two IOSE cells and in three ovarian cancer cells (A2780, BG-1, OVCAR-3), but not in CaOV-3 and SKOV-3 cells (Fig. 3). In addition, treatment with $\mathrm{FSH}$ or $\mathrm{LH}$ for $24 \mathrm{~h}$ resulted in a significant down-regulation of GnRHR mRNA in all the cell lines examined except CaOV-3 cells; however this effect was greater in IOSE cells than in ovarian cancer cells (Fig. 4). For example, in IOSE-80 cells, both FSH and LH decreased GnRHR mRNA in a dose-dependent manner with maximal $60 \%$ and $80 \%$ decreases at $1000 \mathrm{ng} / \mathrm{ml}$ respectively. In contrast, maximal $40 \%$ and $60 \%$ decreases were observed at $1000 \mathrm{ng} / \mathrm{ml} \mathrm{FSH}$ and $\mathrm{LH}$ in OVCAR-3 cells. These data suggest that gonadotropins may differentially regulate the expression of both forms of GnRH and their receptor in ovarian surface epithelium and its neoplastic counterpart.

\section{Effect of FSH and LH treatment on the growth inhibitory effect of GnRH I and GnRH II in IOSE-80 and OVCAR-3 cells}

It has been demonstrated that agonistic analogs of both GnRH I and GnRH II inhibit the growth of IOSE, OVCAR-3 and SKOV-3 cells (Kang et al. 2003). As gonadotropins decreased the mRNA expression of GnRH II and GnRHR, we used the MTT assay to further examine whether gonadotropins modulate the growth inhibition of IOSE80, OVCAR-3 and SKOV-3 cells by GnRH agonists. 

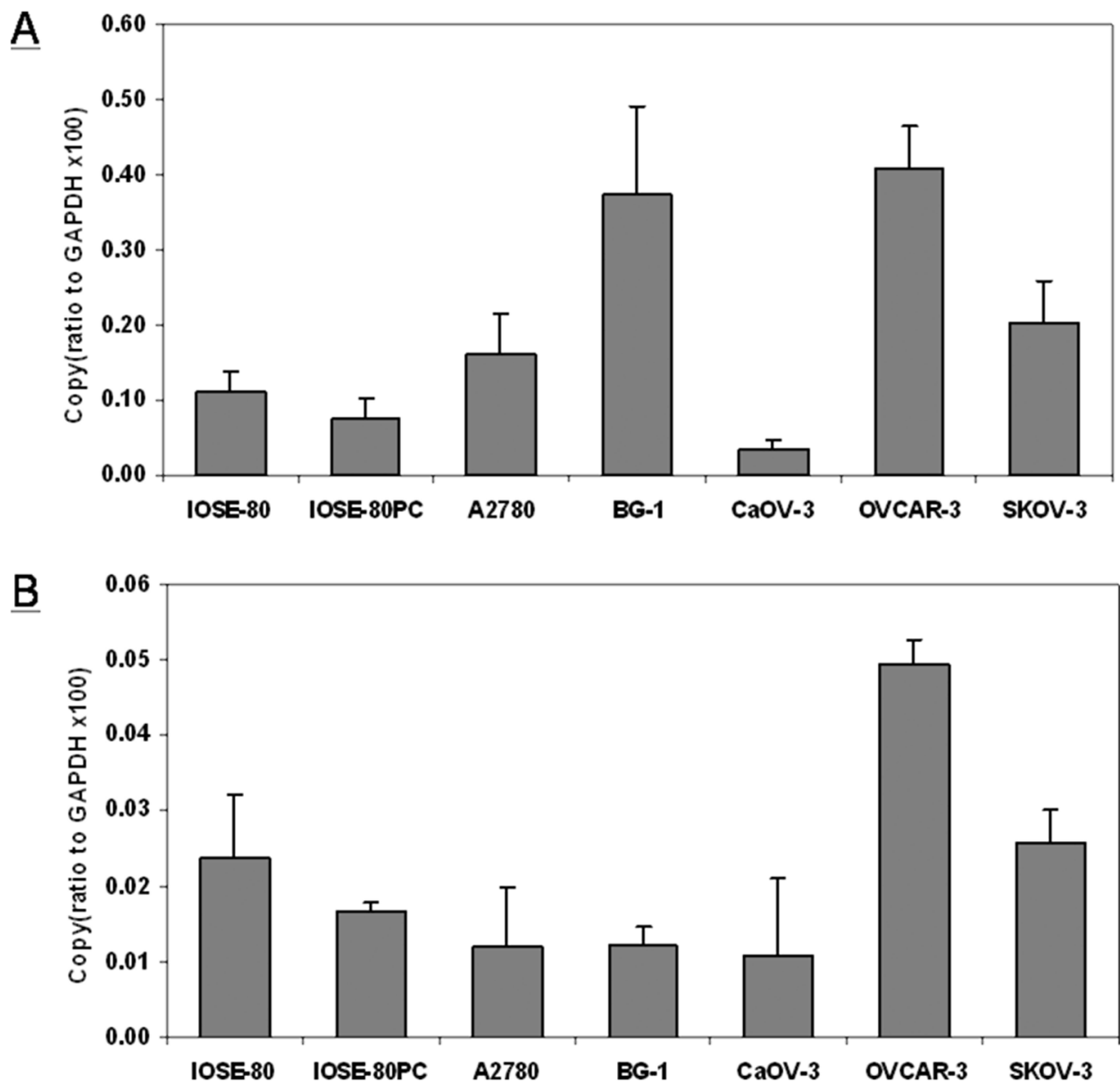

Figure 1 Expression of (A) FSHR and (B) LHR in IOSE and ovarian cancer cells. First-strand cDNA from IOSE-80, IOSE-80PC, A2780, BG-1, CaOV-3, OVCAR-3 and SKOV-3 cells was amplified using two sets of PCR primers shown in Table 1. The expression levels of FSHR and LHR mRNA were normalized against the GAPDH mRNA level. Data are derived from three experiments and are presented as the mean \pm S.D.

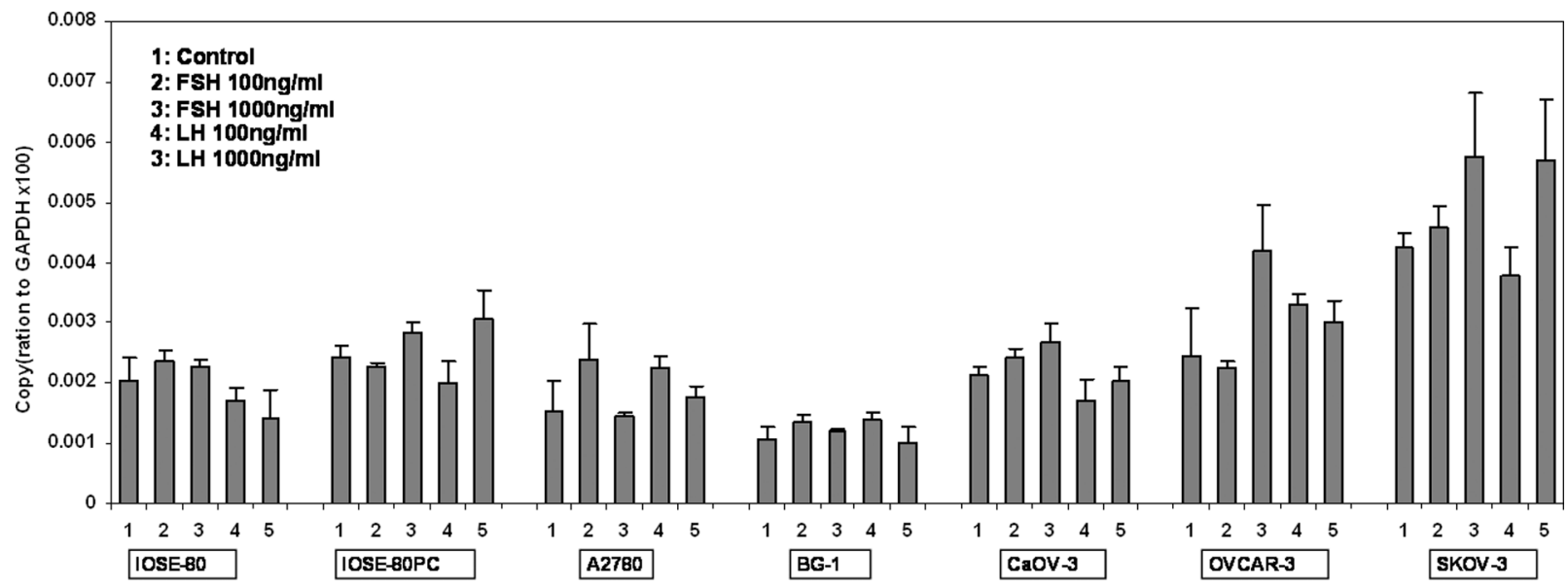

Figure 2 Effect of FSH and LH on GnRHI mRNA in IOSE and ovarian cancer cells. The cells were plated and cultured for $24 \mathrm{~h}$. The cells are then treated with FSH $(100$ and $1000 \mathrm{ng} / \mathrm{ml})$ or $\mathrm{LH}(100$ and $1000 \mathrm{ng} / \mathrm{ml})$ for $24 \mathrm{~h}$. Control cultures were treated with vehicle. Total RNA was extracted and reverse transcribed into first-strand cDNA. The levels of GnRHI mRNA were measured by real-time RT-PCR. Data are presented as the mean \pm S.D. of three experiments. 


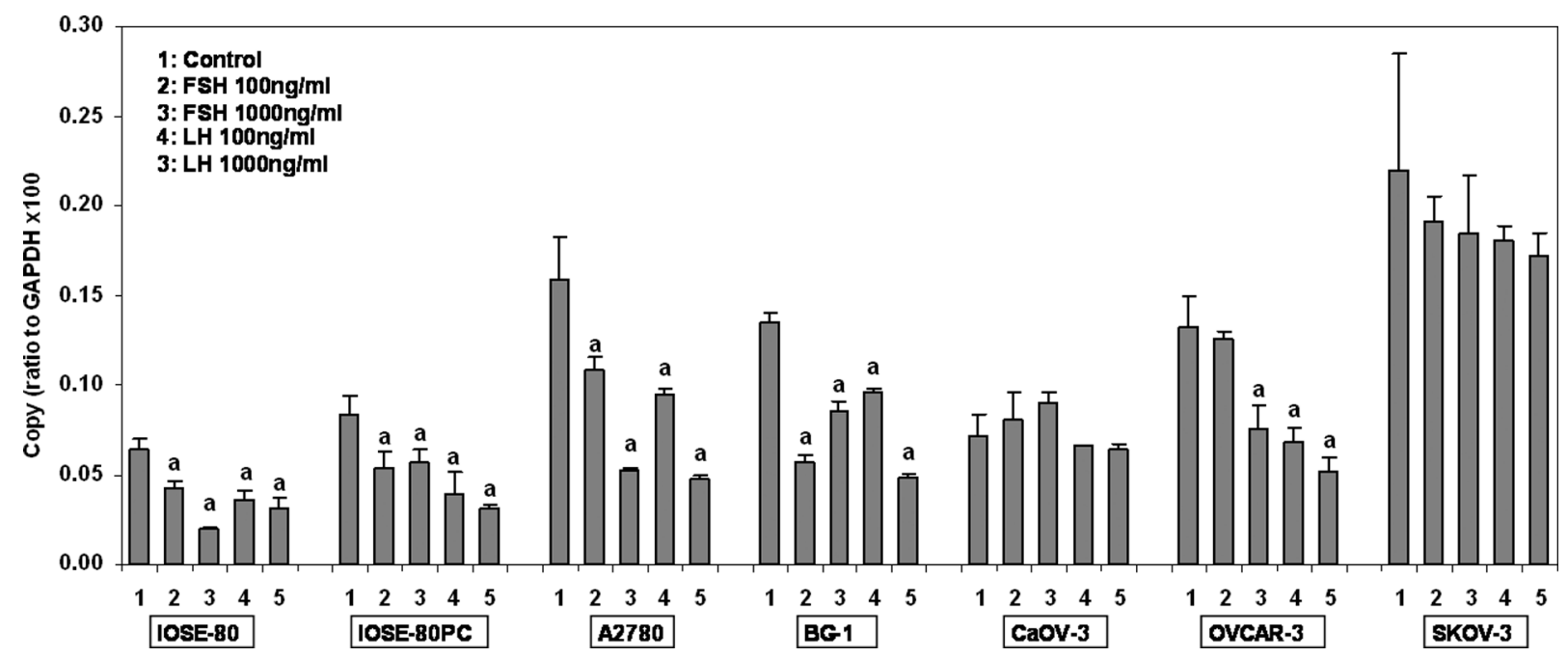

Figure 3 Effect of FSH and LH on GnRHII mRNA in IOSE and ovarian cancer cells. The cells were plated and cultured for $24 \mathrm{~h}$. The cells are then treated with FSH (100 and $1000 \mathrm{ng} / \mathrm{ml})$ or LH (100 and $1000 \mathrm{ng} / \mathrm{ml})$ for $24 \mathrm{~h}$. Control cultures were treated with vehicle. Total RNA was extracted and reverse transcribed into first-strand cDNA. The levels of GnRH II mRNA were measured by real-time RT-PCR. Data are presented as the mean \pm S.D. of three experiments. a, $P<0.05$ compared with the control of each cell line.

The cells were pretreated with gonadotropin (100 ng/ $\mathrm{ml}$ ) or vehicle for $24 \mathrm{~h}$ and then treated with GnRH I or GnRHII agonist $\left(10^{7} \mathrm{M}\right)$, in the presence or absence of gonadotropin, for $48 \mathrm{~h}$. The dose and time of $\mathrm{GnRH}$ treatment $\left(10^{7} \mathrm{M}\right.$ for $\left.48 \mathrm{~h}\right)$ were selected based on a previous study (Kang et al. 2000). In agreement with our previous findings (Choi et al. 2002), treatment with FSH alone resulted in a significant increase in growth of both
IOSE-80 and OVCAR-3 cells, but not SKOV-3 cells. In contrast, treatment with $\mathrm{LH}$ alone showed a mitogenic effect only in OVCAR-3 cells. GnRH I and GnRHII agonists significantly inhibited the growth of all three cell lines examined. Pretreatment with gonadotropins for $24 \mathrm{~h}$ completely reversed the growth-inhibitory effect of GnRHI and GnRH II agonists in IOSE-80 (Fig. 5A), OVCAR-3 (Fig. 5B) and SKOV-3 cells (Fig. 5C).

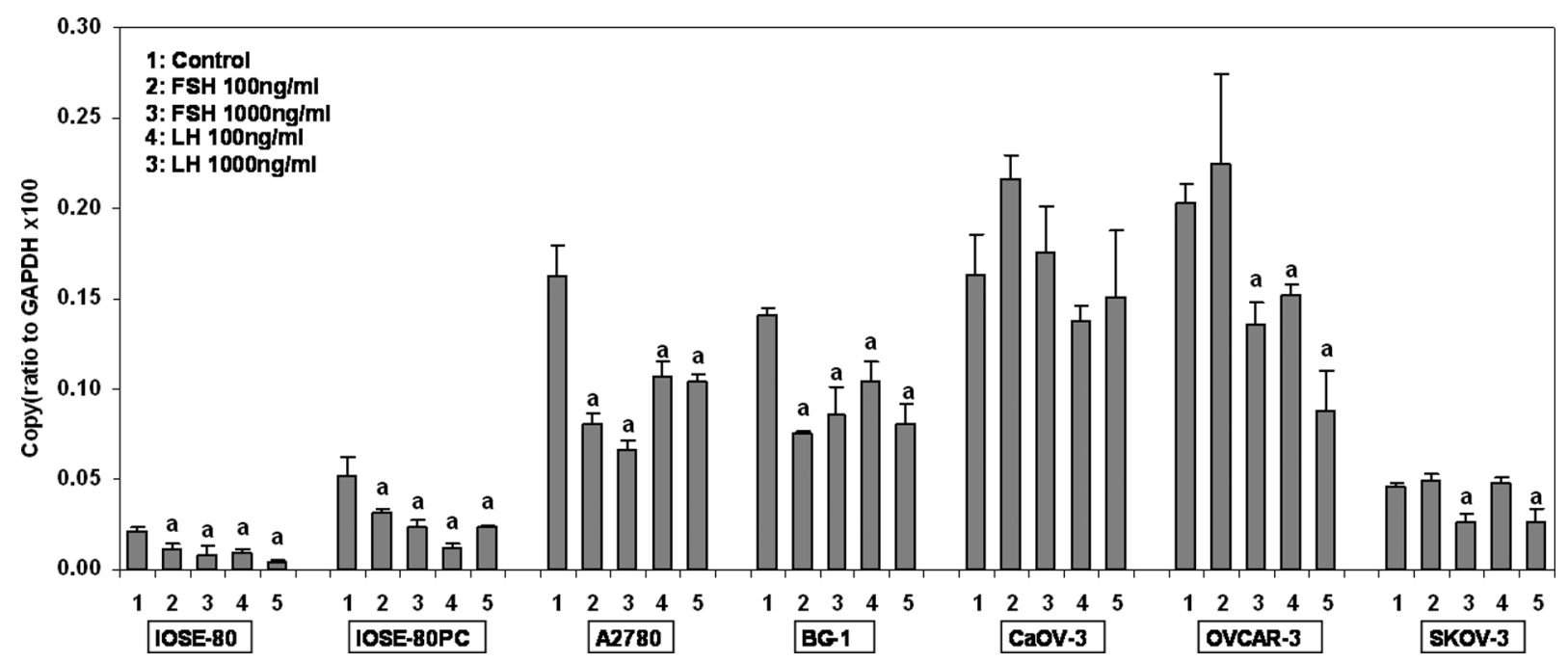

Figure 4 Effect of FSH and LH on GnRHR mRNA in IOSE and ovarian cancer cells. The cells were plated and cultured for $24 \mathrm{~h}$. The cells are then treated with $\mathrm{FSH}(100$ and $1000 \mathrm{ng} / \mathrm{ml})$ or LH (100 and $1000 \mathrm{ng} / \mathrm{ml})$ for $24 \mathrm{~h}$. Control cultures were treated with vehicle. Total RNA was extracted and reverse transcribed into first-strand cDNA. The levels of GnRHR mRNA were measured by real-time RT-PCR. Data are presented as the mean \pm S.D. of three experiments. a, $P<0.05$ compared with the control of each cell line. 
A. IOSE-80

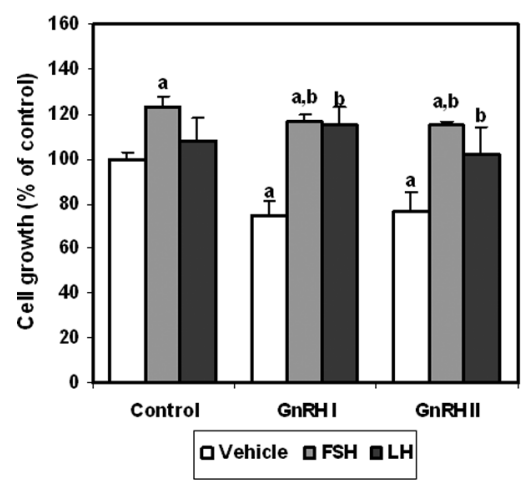

B. OVCAR-3

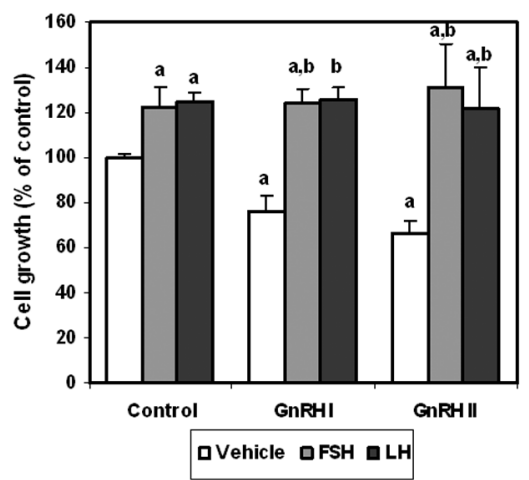

C. SKOV-3

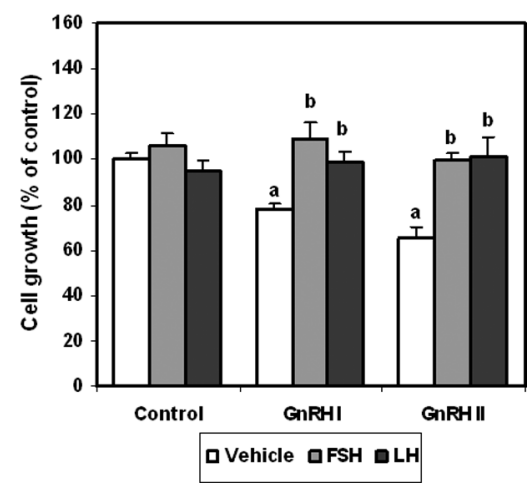

Figure 5 Effect of FSH or LH treatment on the growth inhibitory effect of GnRHI and GnRH II in IOSE-80 cells (A), OVCAR-3 cells (B) and SKOV-3 cells (C). The cells were seeded on 96-well plates and incubated for $24 \mathrm{~h}$. Cells were pretreated with FSH or LH $(100 \mathrm{ng} / \mathrm{ml})$ for $24 \mathrm{~h}$ and then treated with an analog of GnRHI (D-Trp6-GnRH) or GnRH II (D-Arg6-Azagly10-GnRH II) for 2 days. Cell growth was measured using the MTT assay as described in the Materials and methods section. Data are presented as the mean \pm s.D. of three experiments. a, $P<0.05$ compared with control; $\mathrm{b}, P<0.05$ compared with $\mathrm{GnRHI}$ or $\mathrm{GnRHI}$ agonist.

\section{Discussion}

Ovarian cancers, mainly derived from the ovarian surface epithelium, are the most lethal gynecological malignancy and are the fifth leading cause for all cancer deaths in women (Auersperg et al. 2001). There is increasing evidence suggesting the positive or negative effect of reproductive hormones including GnRH and gonadotropins on ovarian cancer initiation and progression (Riman et al. 1998, Risch 1998, Brekelmans 2003). It is of interest that ovarian cancer is more common in conditions with elevated gonadotropins such as post-menopausal women (Holschneider \& Berek 2000, Brekelmans 2003). Reduced risk of ovarian cancer is associated with multiple pregnancies, breast feeding, oral contraceptives, and estrogen replacement therapy which are associated with lower levels and reduced exposure to gonadotropins (Daly \& Obrams 1998, Gnagy et al. 2000, La Vecchia 2001). Moreover, it has been demonstrated that gonadotropin levels of ovarian cyst fluid significantly increase in patients with ovarian cancer as compared with patients with functional and benign ovarian cysts (Halperin et al. 2003, Chudecka-Glaz et al. 2004).

The expression of FSHR and LHR in normal OSE and ovarian cancer cells has been demonstrated (Kobayashi et al. 1996, Mandai et al. 1997, Minegishi et al. 2000, Zheng et al. 2000, Parrott et al. 2001). However, the role of FSH and LH in normal OSE and ovarian epithelial cancer is not well characterized. Although a gonadotropin theory that they may be involved in the development of epithelial ovarian cancer is still controversial to date (Wimalasena et al. 1991, Venn et al. 1995, Ivarsson et al. 2001, Tourgeman et al. 2002), it is assumed that FSH and LH/hCG stimulate the growth of normal, immortalized OSE and some ovarian cancer cells in a doseand time-dependent manner in vitro (Wimalasena et al. 1992, Kurbacher et al. 1995, Ohtani et al. 2001, Parrott et al. 2001, Syed et al. 2001, Choi et al. 2002). In the present study, we examined the alteration in GnRHI, GnRHII and GnRHR mRNA expression in human OSE and ovarian cancer cells by $\mathrm{FSH}$ and $\mathrm{LH}$ at concentrations that are associated with the relatively high levels of gonadotropins in post-menopausal women. After the menopause there is a 10- to 20-fold increase in gonadotropins compared with basal levels in the normal reproductive cycle. We also examined the ability of gonadotropins to modulate the growth-inhibitory effects of two forms of GnRHs.

GnRH I and its receptor are expressed in $80 \%$ of human OSE cells and ovarian cancer cell lines (Emons et al. 1993, Miyazaki et al. 1997), suggesting that this decapeptide may be an autocrine and/or paracrine regulator of the OSE and may play a role in the pathophysiology of ovarian cancer (Savino et al. 1992, Schally 1999, Schally et al. 2001, Grundker \& Emons 2003, Kang et al. 2003). In the present study, we found that four out of five ovarian cancer cell lines (A2780, BG-1, CaOV-3 and OVCAR-3) highly expressed basal GnRHR compared with IOSE cells. This is consistent with a recent report that primary ovarian cancer cells expressed higher levels of GnRHR compared with normal ovarian tissues using RT-PCR, immunohistochemistry and Western blot assay. For instance, 
the mean values of fold-increase of GnRHR mRNA level in stage I-IV ovarian cancer were 2.24, 2.58, 3.10 and 3.20 as compared with normal ovarian tissues, and overall $70 \%(21 / 30)$ of ovarian cancer tissues had increased GnRHR mRNA levels.

As shown in Figs 2 and 3, SKOV-3 cells with potential invasiveness in our cell culture system highly expressed both GnRH I and GnRH II compared with IOSE cells, whereas other ovarian cancer cells including A2780, BG-1 and OVCAR-3 showed modest increased levels of GnRHII. Whether the expression of GnRHs as well as their receptor could be used to characterize the histological type, stage or grade of human ovarian epithelial cancer remains to be determined. In view of the recent observation that the $\mathrm{GnRH} / \mathrm{GnRHR}$ system can be modulated by gonadotropins in hypothalamic GT1-7 neuron and human granulosa luteal cells (Lei \& Rao 1994, Kang et al. 2001c), we hypothesized that gonadotropins would interact with the GnRH/GnRHR system to regulate cell growth in OSE and ovarian cancer cells. This hypothesis is supported by the results of the present study that GnRHII and/or GnRHR mRNA levels are down-regulated by gonadotropin in IOSE cells and ovarian cancer cells. It cannot be explained why the regulatory effect of gonadotropin on the GnRH/GnRHR system is relatively weak in SKOV-3 cells, such that FSH and $\mathrm{LH}$ can modulate only GnRHR (with a maximum 40\% decrease), and is absent in CaOV-3 cells. Our results suggest that the two forms of $\mathrm{GnRH}$ are differentially regulated under various physiological conditions. Indeed, in the brain of the female European silver eel, steroids induce an increase in mammalian (m) GnRH and a decrease in chicken (c) GnRH II (Montero et al. 1995). In the chicken, only the level of $\mathrm{mGnRH}$ in the hypothalamus was modified by castration (Sun et al. 2001). In the goldfish, the ratio between salmon GnRH and cGnRH II changes with sexual maturation (Rosenblum et al. 1994).

Treatment of human GL cells with FSH and hCG resulted in a marked increase in GnRH II mRNA levels but decreased those of GnRH I (Kang et al. 2001c). This differential regulation of two forms of $\mathrm{GnRH}$ by various factors including gonadotropins in a range of cell types suggests the distinct spatial expression and function of these peptides. Furthermore, considering the growth inhibitory effect of GnRH, decreased expression of GnRH II or the GnRH II/GnRH I ratio may play a critical role in the development of ovarian cancer by regulating proliferation. The reason why gonadotropins differentially regulate the transcription of GnRH I and GnRH II genes is not clear. It is possible that two distinct transcription mechanisms exist for each $\mathrm{GnRH}$ in the ovary and that gonadotropins regulate only the GnRHII-related mechanism. Further study is required to elucidate the physiological relevance and the mechanism of the differential regulation of GnRH I and GnRH II by gonadotropins.

Previously, we and others demonstrated that treatment with GnRHI and GnRH II inhibits the proliferation of IOSE and ovarian cancer cells as determined by thymidine incorporation (Grundker \& Emons 2003, Kang et al. 2003). In this study, we further explored the possibility that gonadotropins may antagonize the growth inhibitory effect of GnRHI and GnRHII in IOSE, OVCAR-3 and SKOV-3 cells by regulating the expression levels of GnRH ligands and their receptor. The growthinhibitory effect of GnRHI and GnRHII was substantiated further in the present study using the MTT assay. A decrease in cell number of approximately $20 \%$ was observed in response to GnRH I or GnRH II in IOSE-80, OVCAR-3 and SKOV-3 cells, and this effect was reversed by pretreatment with FSH or LH. These results indicate that gonadotropins may function as growth regulators in IOSE80, OVCAR-3 and SKOV-3 cells. The mechanism of action of gonadotropins in this regard is not clear. We cannot rule out the possibility that the mitogenic activity of gonadotropins may override the growth inhibitory activity of GnRH analogs independent of down-regulation of GnRHII and GnRHR in these cells. As shown in Fig. 5C, pretreatment with gonadotropin, which is not a mitogen in SKOV-3 cells, reversed GnRH analog-inhibited cell growth. This result suggests that the mechanism of action of gonadotropins may include, at least in part, a reduction in GnRH II and GnRHR mRNA levels. In addition, the effects of FSH and $\mathrm{LH}$ in these cells may also be indirect via other growth factors. For instance, combined treatment with hCG and estradiol may regulate the growth of epithelial ovarian cancer cells through the insulin-like growth factor-I pathway (Wimalasena et al. 1993). Likewise, FSH and hCG stimulate steady state mRNA levels of keratinocyte growth factor, hepatocyte growth factor and kit ligand in bovine OSE cells (Parrot 2001). Recently, we have demonstrated that treatment of immortalized OSE and OVCAR-3 cells with FSH and LH significantly increased EGFR mRNA and protein (Choi et al. 2005). 
In summary, a significant decrease in GnRH II and GnRHR mRNA levels was observed in IOSE and ovarian cancer cells following treatment with FSH or LH. In contrast, treatment with either FSH or LH had no effect on GnRHI mRNA levels in the cell lines employed, suggesting that gonadotropins regulate these two forms of GnRH and its receptor differentially. Pretreatment of the cells with FSH or LH significantly reversed the growth inhibitory effect of GnRHI and GnRHII agonists in IOSE80, OVCAR-3 and SKOV-3 cells. Taken together, these results suggest that FSH and $\mathrm{LH}$ may interact with the GnRH system to control the growth of ovarian surface epithelial cells and their neoplastic counterparts.

\section{Acknowledgements}

This work was supported by the Canadian Institutes of Health Research. PCKL is the recipient of a Distinguished Scholar Award from the Michael Smith Foundation for Health Research. JHC is the recipient of a Graduate Studentship Award from the BC Research Institute for Children's and Women's Health. We are grateful to Dr Christian Klausen at the British Columbia Research Institute for Children's and Women's Health, University of British Columbia for critical review of the manuscript. The authors declare that there is no conflict of interest that would prejudice the impartiality of this scientific work.

\section{References}

Auersperg N, Wong AS, Choi KC, Kang SK \& Leung PC 2001 Ovarian surface epithelium: biology, endocrinology, and pathology. Endocrine Reviews 22 255-288.

Brekelmans CT 2003 Risk factors and risk reduction of breast and ovarian cancer. Current Opinion in Obstetics and Gynecology 15 63-68.

Cheng CK \& Leung PC 2005 Molecular biology of gonadotropin-releasing hormone (GnRH)-I, GnRH-II, and their receptors in humans. Endocrine Reviews $\mathbf{2 6}$ 283-306.

Choi KC, Kang SK, Nathwani PS, Cheng KW, Auersperg N \& Leung PC $2001 a$ Differential expression of activin/ inhibin subunit and activin receptor mRNAs in normal and neoplastic ovarian surface epithelium (OSE). Molecular and Cellular Endocrinology 174 99-110.

Choi KC, Kang SK, Tai CJ, Auersperg N \& Leung PC $2001 b$ Estradiol up-regulates antiapoptotic Bcl-2 messenger ribonucleic acid and protein in tumorigenic ovarian surface epithelium cells. Endocrinology 142 2351-2360.
Choi KC, Kang SK, Tai CJ, Auersperg N \& Leung PC 2002 Follicle-stimulating hormone activates mitogen-activated protein kinase in preneoplastic and neoplastic ovarian surface epithelial cells. Journal of Clinical Endocrinology and Metabolism $\mathbf{8 7}$ 2245-2253.

Choi JH, Choi KC, Auersperg N \& Leung PC 2004 Overexpression of follicle-stimulating hormone receptor activates oncogenic pathways in preneoplastic ovarian surface epithelial cells. Journal of Clinical Endocrinology and Metabolism $895508-5516$.

Choi JH, Choi KC, Auersperg N \& Leung PC 2005 Gonadotropins upregulate the epidermal growth factor receptor through activation of mitogen-activated protein kinases and phosphatidyl-inositol-3-kinase in human ovarian surface epithelial cells. Endocrine-Related Cancer 12 407-421.

Chudecka-Glaz A, Rzepka-Gorska I \& Kosmowska B 2004 Gonadotropin (LH, FSH) levels in serum and cyst fluid in epithelial tumors of the ovary. Archives in Gynecology and Obstetics 270 151-156.

Daly M \& Obrams GI 1998 Epidemiology and risk assessment for ovarian cancer. Seminars in Oncology 25 255-264.

Dong KW, Yu KL \& Roberts JL 1993 Identification of a major up-stream transcription start site for the human progonadotropin-releasing hormone gene used in reproductive tissues and cell lines. Molecular Endocrinology 7 1654-1666.

Emons G, Ortmann O, Becker M, Irmer G, Springer B, Laun R, Holzel F, Schulz KD \& Schally AV 1993 High affinity binding and direct antiproliferative effects of LHRH analogues in human ovarian cancer cell lines. Cancer Research 53 5439-5446.

Gnagy S, Ming EE, Devesa SS, Hartge P \& Whittemore AS 2000 Declining ovarian cancer rates in US women in relation to parity and oral contraceptive use. Epidemiology 11 102-105.

Grundker C \& Emons G 2003 Role of gonadotropinreleasing hormone $(\mathrm{GnRH})$ in ovarian cancer. Reproductive Biology and Endocrinology 165.

Halperin R, Pansky M, Vaknin Z, Zehavi S, Bukovsky I \& Schneider D 2003 Luteinizing hormone in peritoneal and ovarian cyst fluids: a predictor of ovarian carcinoma. European Journal of Obstetics and Gynecological Reproductive Biology 110 207-210.

Holschneider CH \& Berek JS 2000 Ovarian cancer: epidemiology, biology, and prognostic factors. Seminars in Surgical Oncology 19 3-10.

Ivarsson K, Sundfeldt K, Brannstrom M, Hellberg P \& Janson PO 2001 Diverse effects of FSH and LH on proliferation of human ovarian surface epithelial cells. Human Reproduction 16 18-23.

Kang SK, Choi KC, Cheng KW, Nathwani PS, Auersperg N \& Leung PC 2000 Role of gonadotropinreleasing hormone as an autocrine growth factor in human ovarian surface epithelium. Endocrinology 141 $72-80$. 
Kang SK, Choi KC, Tai CJ, Auersperg N \& Leung PC $2001 a$ Estradiol regulates gonadotropin-releasing hormone $(\mathrm{GnRH})$ and its receptor gene expression and antagonizes the growth inhibitory effects of GnRH in human ovarian surface epithelial and ovarian cancer cells. Endocrinology 142 580-588.

Kang SK, Tai CJ, Nathwani PS, Choi KC \& Leung PC $2001 b$ Stimulation of mitogen-activated protein kinase by gonadotropin-releasing hormone in human granulosaluteal cells. Endocrinology 142 671-679.

Kang SK, Tai CJ, Nathwani PS \& Leung PC 2001c Differential regulation of two forms of gonadotropinreleasing hormone messenger ribonucleic acid in human granulosa-luteal cells. Endocrinology 142 182-192.

Kang SK, Choi KC, Yang HS \& Leung PC 2003 Potential role of gonadotrophin-releasing hormone ( $\mathrm{GnRH})-\mathrm{I}$ and GnRH-II in the ovary and ovarian cancer. EndocrineRelated Cancer 10 169-177.

Khosravi S \& Leung PC 2003 Differential regulation of gonadotropin-releasing hormone (GnRH) I and GnRH II messenger ribonucleic acid by gonadal steroids in human granulosa luteal cells. Journal of Clinical Endocrinology and Metabolism 88 663-672.

Kobayashi F, Monma C, Nanbu K, Konishi I, Sagawa N \& Mori T 1996 Rapid growth of an ovarian clear cell carcinoma expressing $\mathrm{LH} / \mathrm{hCG}$ receptor arising from endometriosis during early pregnancy. Gynecology and Oncology 62 309-313.

Kurbacher CM, Jager W, Kurbacher JA, Bittl A, Wildt L \& Lang N 1995 Influence of human luteinizing hormone on cell growth and CA 125 secretion of primary epithelial ovarian carcinomas in vitro. Tumour Biology 16 374-384.

La Vecchia C 2001 Epidemiology of ovarian cancer: a summary review. European Journal of Cancer Prevention 10 125-129.

Lei ZM \& Rao CV 1994 Novel presence of luteinizing hormone/human chorionic gonadotropin (hCG) receptors and the down-regulating action of hCG on gonadotropin-releasing hormone gene expression in immortalized hypothalamic GT1-7 neurons. Molecular Endocrinology 8 1111-1121.

Lescheid DW, Terasawa E, Abler LA, Urbanski HF, Warby CM, Millar RP \& Sherwood NM 1997 A second form of gonadotropin-releasing hormone $(\mathrm{GnRH})$ with characteristics of chicken GnRH-II is present in the primate brain. Endocrinology 138 5618-5629.

Mandai M, Konishi I, Kuroda H, Fukumoto M, Komatsu T, Yamamoto S, Nanbu K, Rao CV \& Mori T 1997 Messenger ribonucleic acid expression of $\mathrm{LH} / \mathrm{hCG}$ receptor gene in human ovarian carcinomas. European Journal of Cancer 33 1501-1507.

Minegishi T, Kameda T, Hirakawa T, Abe K, Tano M \& Ibuki Y 2000 Expression of gonadotropin and activin receptor messenger ribonucleic acid in human ovarian epithelial neoplasms. Clinical Cancer Research 6 2764-2770.
Miyazaki M, Nagy A, Schally AV, Lamharzi N, Halmos G, Szepeshazi K, Groot K \& Armatis P 1997 Growth inhibition of human ovarian cancers by cytotoxic analogues of luteinizing hormone-releasing hormone. Journal of the National Cancer Institute 89 1803-1809.

Montero M, Le Belle N, King JA, Millar RP \& Dufour S 1995 Differential regulation of the two forms of gonadotropin-releasing hormone ( $\mathrm{mGnRH}$ and cGnRHII) by sex steroids in the European female silver eel (Anguilla anguilla). Neuroendocrinology 61 525-535.

Nagata S \& Golstein P 1995 The Fas death factor. Science 267 1449-1456.

Ohta H, Sakamoto H \& Satoh K 1998 In vitro effects of gonadotropin-releasing hormone $(\mathrm{GnRH})$ analogue on cancer cell sensitivity to cis-platinum. Cancer Letters 134 $111-118$.

Ohtani K, Sakamoto H, Kikuchi A, Nakayama Y, Idei T, Igarashi N, Matukawa T \& Satoh K 2001 Folliclestimulating hormone promotes the growth of human epithelial ovarian cancer cells through the protein kinase C-mediated system. Cancer Letters 166 207-213.

Olofsson JI, Conti CC \& Leung PC 1995 Homologous and heterologous regulation of gonadotropin-releasing hormone receptor gene expression in preovulatory rat granulosa cells. Endocrinology 136 974-980.

Parrott JA, Doraiswamy V, Kim G, Mosher R \& Skinner MK 2001 Expression and actions of both the folliclestimulating hormone receptor and the luteinizing hormone receptor in normal ovarian surface epithelium and ovarian cancer. Molecular and Cellular Endocrinology 172 213-222.

Peng C, Fan NC, Ligier M, Vaananen J \& Leung PC 1994 Expression and regulation of gonadotropin-releasing hormone $(\mathrm{GnRH})$ and $\mathrm{GnRH}$ receptor messenger ribonucleic acids in human granulosa-luteal cells. Endocrinology 135 1740-1746.

Pon YL, Auersperg N \& Wong AS 2005 Gonadotropins regulate $\mathrm{N}$-cadherin-mediated human ovarian surface epithelial cell survival at both post-translational and transcriptional levels through a cyclic $\mathrm{AMP} /$ protein kinase A pathway. Journal of Biological Chemistry 280 $15438-15448$.

Riman T, Persson I \& Nilsson S 1998 Hormonal aspects of epithelial ovarian cancer: review of epidemiological evidence. Clinical Endocrinology 49 695-707.

Risch H 1998 Hormonal etiology of epithelial ovarian cancer, with a hypothesis concerning the role of androgens and progesterone. Journal of the National Cancer Institute 90 1774-1786.

Rosenblum PM, Goos HJ \& Peter RE 1994 Regional distribution and in vitro secretion of salmon and chickenII gonadotropin-releasing hormones from the brain and pituitary of juvenile and adult goldfish, Carassius auratus. General and Comparative Endocrinology $\mathbf{9 3}$ 369-379.

Savino L, Baldini B, Susini T, Pulli F, Antignani L \& Massi GB 1992 GnRH analogs in gynecological oncology: a review. Journal of Chemotherapy 4 312-320. 
Schally AV 1999 Luteinizing hormone-releasing hormone analogs: their impact on the control of tumorigenesis. Peptides 20 1247-1262.

Schally AV, Comaru-Schally AM, Nagy A, Kovacs M, Szepeshazi K, Plonowski A, Varga JL \& Halmos G 2001 Hypothalamic hormones and cancer. Frontiers in Neuroendocrinology 22 248-291.

Shoham Z 1994 Epidemiology, etiology, and fertility drugs in ovarian epithelial carcinoma: where are we today? Fertility and Sterility 62 433-448.

Sun YM, Flanagan CA, Illing N, Ott TR, Sellar R, Fromme BJ, Hapgood J, Sharp P, Sealfon SC \& Millar RP 2001 A chicken gonadotropin-releasing hormone receptor that confers agonist activity to mammalian antagonists. Identification of D-Lys(6) in the ligand and extracellular loop two of the receptor as determinants. Journal of Biological Chemistry $\mathbf{2 7 6}$ 7754-7761.

Syed V, Ulinski G, Mok SC, Yiu GK \& Ho SM 2001 Expression of gonadotropin receptor and growth responses to key reproductive hormones in normal and malignant human ovarian surface epithelial cells. Cancer Research $616768-6776$.

Tang X, Yano T, Osuga Y, Matsumi H, Yano N, Xu J, Wada O, Koga K, Kugu K, Tsutsumi O, Schally AV \& Taketani Y 2002 Cellular mechanisms of growth inhibition of human epithelial ovarian cancer cell line by LH-releasing hormone antagonist Cetrorelix. Journal of Clinical Endocrinology and Metabolism 87 3721-3727.

Tourgeman DE, Lu JJ, Boostanfar R, Amezcua C, Felix JC \& Paulson RJ 2002 Human chorionic gonadotropin suppresses ovarian epithelial neoplastic cell proliferation in vitro. Fertility and Sterility 78 1096-1099.

Venn A, Watson L, Lumley J, Giles G, King C \& Healy D 1995 Breast and ovarian cancer incidence after infertility and in vitro fertilisation. Lancet 346 995-1000.

Wimalasena J, Meehan D \& Cavallo C 1991 Human epithelial ovarian cancer cell steroid secretion and its control by gonadotropins. Gynecology and Oncology 41 56-63.

Wimalasena J, Dostal R \& Meehan D 1992 Gonadotropins, estradiol, and growth factors regulate epithelial ovarian cancer cell growth. Gynecology and Oncology 46 345-350.

Wimalasena J, Meehan D, Dostal R, Foster JS, Cameron M \& Smith M 1993 Growth factors interact with estradiol and gonadotropins in the regulation of ovarian cancer cell growth and growth factor receptors. Oncology Research 5 325-337.

Zheng W, Lu JJ, Luo F, Zheng Y, Feng Y, Felix JC, Lauchlan SC \& Pike MC 2000 Ovarian epithelial tumor growth promotion by follicle-stimulating hormone and inhibition of the effect by luteinizing hormone. Gynecology and Oncology 76 80-88. 
